\title{
O NOVO CPC, OS PRECEDENTES VINCULANTES E A DISCUSSÃO SOBRE A (IN) CONSTITUCIONALIDADE DE SUA PREVISÃO INFRACONSTITUCIONAL
}

\author{
THE NEW CPC, THE BINDING PRECEDENTS AND THE DISCUSSION ON THE (IN) \\ CONSTITUTIONALITY OF ITS INFRACONSTITUTIONAL FORECAST
}

Rogerio Mollica

\begin{abstract}
Mestre e Doutor em Direito Processual pela Universidade de São Paulo. Professor dos Programas de Mestrado e Doutorado em Direito da Universidade de Marília - Unimar-SP.

E-mail: rogerio.mollica@mrlaw.com.br
\end{abstract}

Ocimar Barros de Oliveira

Graduado em Direito e Educação Física pela Universidade Federal de Uberlândia; Especialista e Mestre em Dirieito pela Universidade Federal de Uberlândia, Doutorando em Direito pela Universidade de Marília-Unimar, Professor do Centro de Ensino Superior de São Gotardo-CESG, Oficial do Registro de Títulos e Documentos e Registro Civil das Pessoas Jurídicas da Comarca de Rio Paranaíba-MG.

E-mail: aspex37@yahoo.com.br

Recebido em: 20/02/2018

Aprovado em: 12/11/2018

RESUMO: A novel Lei 13.105 de 16 de março de 2015, Código de Processo Civil brasileiro, trouxe como uma de suas inovações os precedentes vinculantes, previstos no art. 927, também denominados precedentes normativos. Desde a publicação do novo CPC os juristas se dividiram em dois grupos: um que argui a inconstitucionalidade do instituto previsto no art. 927 do Código e outro que defende a constitucionalidade da previsão infraconstitucional. O presente estudo visa analisar os precedentes vinculantes em sua conceituação, origem, diferenciação e aproximação entre os sistemas do common law e civil law e, em especial, as fundamentações de ambas as correntes, no intuito de lançar lume sobre eventuais inconstitucionalidades de sua previsão em lei ordinária e ausência de autorização constitucional.

Palavras-Chave: Precedentes Vinculantes. Novo Código de Processo Civil. Inconstitucionalidade. Constitucionalidade.

ABSTRACT: The novel Law 13,105 of March 16, 2015, Code of Brazilian Civil Procedure, brought as one of its innovations the binding precedents, foreseen in art. 927, also called normative precedents. Since the publication of the new CPC, jurists have been divided into two groups: one that argues the unconstitutionality of the institute provided for in art. 927 of the Code and another that defends the constitutionality of infraconstitutional forecasting. The present study aims at analyzing binding precedents in its conceptualization, origin, differentiation and approximation 
between common law and civil law systems and, in particular, the bases of both currents, in order to throw light on possible unconstitutionalities of its prediction in ordinary law and absence of constitutional authorization.

Key words: binding precedents; new Code of Civil Procedure; Unconstitutionality; constitutionality.

SUMÁRIO: Introdução. 1. Neoconstitucionalismo, pós-positivismo e aproximação entre os sistemas da common law e civil law. 2. Definições importantes para se entender o sistema dos precedentes baseado no common law. 3. Definição de precedentes vinculantes e classificação dos tipos de eficácia dos precedentes judiciais. 3.1. Diferença entre jurisprudência, súmula e precedente. 3.2. Tipos de eficácia dos precedentes judiciais. 3.2.1. Precedente vinculante. 3.2.2. Precedentes de eficácia intermediária. 3.2.3. Precedentes de eficácia persuasiva. 4. Da (in)constitucionalidade dos precedentes vinculantes previstos no art. 927, III, IV e V do CPC. 4.1. Juristas que defendem a inconstitucionalidade dos precedentes vinculantes. 4.2. Juristas que defendem a constitucionalidade dos precedentes vinculantes. Conclusão. Referências.

\section{INTRODUÇÃO}

O novo Código de Processo Civil brasileiro, publicado em 16 de março de 2015, entrou em vigor em 18 de março de 2016, um ano após sua publicação, trazendo inovações e questionamentos que dividiram os juristas brasileiros. Destaca-se neste estudo o instituto dos precedentes vinculantes (precedentes normativos), que proporcionaram uma discussão quanto à possibilidade de serem inconstitucionais, em especial os incisos III a V, do art. 927, do Código em comento, por terem ingressado no ordenamento jurídico pátrio por meio de lei ordinária.

O novo CPC, logo em seu primeiro artigo, assume o compromisso público de ser ordenado, disciplinado e interpretado conforme os valores e as normas fundamentais estabelecidas na Constituição da República Federativa do Brasil, ou seja, no discurso inicial reconhece a Constituição como norma vértice do ordenamento jurídico pátrio.

Reputa-se um tanto redundante e desnecessário tal compromisso do artigo primeiro do Código de Processo Civil de 2015, poder-se-ia entender até mesmo como excesso de zelo do legislador ordinário, haja vista que qualquer manual de Introdução ao Estudo do Direito, dos anos iniciais dos cursos de Direito, tratará da hierarquia das leis e apontará a Constituição Federal como Lei Maior da República.

A grande crítica que alguns juristas têm feito é quanto à distância entre este discurso inicial e o tratamento infraconstitucional dado, em especial aos precedentes vinculantes, pois, se os precedentes judiciais emanam de órgãos que não têm mandato do povo para editar dispositivos com conteúdo normativo, então atribuiu-se à autorização constitucional uma vinculação secundária em relação a tais precedentes. Seria o mesmo que dizer que o CPC, como lei ordinária, usurpou o status da Carta Magna e subverteu a tão propalada hierarquia das leis.

Há ainda aqueles que tecem severas críticas ao instituto trazido ao ordenamento pátrio pelo art. 927 do CPC, pois entendem que na verdade o pano de fundo dos precedentes vinculantes seria mais para servir como filtro (peneira) para que o Judiciário se livre de milhões de processos que abarrotam os juízos e tribunais e, porque não dizer, causam entraves e vergonha à atividade forense.

A esse respeito assim se posiciona Marcelo Abelha: 
A mágica inventada pelo legislador são os filtros redutores de ações e recursos, peneiras de eliminação não apenas das demandas e recursos que estão em curso, mas daquelas que ainda estão por vir. Quando o sujeito pensar em propor a ação contra a taxa ou desconto bancário indevido, contra o mau serviço de telefonia, contra os abusos do Poder Público, nada poderá fazer porque sua lide já teria sido julgada em casos repetitivos já julgados. (2016, p. 316)

Tudo isso sem garantia de que se faça a justiça pelo devido e justo processo legal, garantia fundamental do jurisdicionado, que terá seu caso enquadrado numa moldura criada pelo precedente, cabendo ao juízo ou tribunal vinculado apenas analisar em qual moldura se enquadra cada caso. Isto equivale a dizer que o precedente à brasileira seria o mesmo que transformar o juiz brasileiro de ator que domina a nobre arte do direito, analisando fatos e normas jurídicas e esculpindo, num trabalho de Hermes, fundamentos de casos concretos (ratio decidendi), em um mero coadjuvante, que apenas emoldura a arte por outrem produzida.

$\mathrm{Na}$ certeza de que não há como importar, na sua essência, um sistema estrangeiro (precedente do common law) que fora construído ao longo dos séculos de labor judicial e aplicá-lo ao ordenamento pátrio, construído como grande edifício legislativo (civil law), com auxílio do trabalho não menos valoroso da doutrina e jurisprudência, é que os autores do anteprojeto do novo CPC, tentaram, sem escapar das críticas, "criar" um sistema de precedentes "à brasileira".

O cerne do presente estudo está em analisar os precedentes comparando os dois sistemas, common law e civil law, abordar uma breve conceituação dos institutos que dão sustentáculo aos precedentes, bem como trazer a lume os posicionamentos das correntes que defendem a constitucionalidade e a inconstitucionalidade dos precedentes propostos no art. 927 do CPC, em especial em seus incisos III a V.

O presente trabalho adota uma postura analógica, com base em pesquisa bibliográfica, e visa apontar as teses, vantagens e críticas de cada uma delas, ao final conclui-se que, não obstante exista uma corrente que brade pela inconstitucionalidade dos precedentes vinculantes, por alegado vício formal, o instituto é relevante para consecução de um dos direitos fundamentais do cidadão brasileiro, a saber, a razoável duração do processo.

\section{NEOCONSTITUCIONALISMO, PÓS-POSITIVISMO E APROXIMAÇÃO ENTRE OS SISTEMAS DA COMMON LAW E CIVIL LAW}

Após os horrores da Segunda Guerra Mundial, ocorrida ao final da primeira metade do século XX, evento no qual nazismo e facismo, apoiados no positivismo jurídico, deixaram uma grande mácula na história humana, inaugura-se uma nova era para o direito constitucional, pautada na necessidade de se garantir liberdades, direitos individuais e coletivos e também direitos sociais, que viessem a promover a tão almejada dignidade da pessoa humana.

O movimento neoconstitucionalista que se iniciou na Europa, mais precisamente com a Constituição Italiana de 1947 e com a Lei Fundamental de Bonn de 1949, na Alemanha, redundando na criação de cortes constitucionais, espalhou-se para outros países da Europa e, finalmente, chegou ao Brasil com a Constituição de 1988.

Filippo destaca que:

No Brasil houve campo propício para sua adoção somente após a Constituição de 1988. Sem ela, seria inviável a sua invocação, mas o texto se constituiu ato deflagrador necessário para que se forjasse uma hermenêutica peculiar e seus preceitos pudessem ser concretizados pela jurisdição constitucional. (2015, p. 429) 
O movimento iniciado pelo neoconstitucionalismo propiciou que houvesse uma abertura maior para que os dois sistemas, common law e civil law, tivessem uma inegável aproximação. No mesmo entendimento dispõe Filippo:

Realmente, observamos que a partir dessa abertura do sistema gerada pelo neoconstitucionalismo, tem havido uma aproximação do direito brasileiro ao common law, ocasionada pela necessidade de se conferir maior segurança e previsibilidade às decisões judiciais, medida que de fato se afina ao princípio da isonomia e de inegável importância para outros setores, atendendo, por exemplo, aos reclames do desenvolvimento econômico, justamente pela minimização dos riscos e consequente estímulo aos investidores. (2015, p. 434/435)

Importante salientar que a aproximação entre common law e civil law, que teve grande impulso no contexto do neoconstitucionalismo, sofreu influência do pós-positivismo, embora, notadamente, traga consigo resquícios do positivismo kelseniano.

Kelsen defende que "os tribunais são órgãos legislativos exatamente no mesmo sentido em que o órgão é chamado de legislativo no sentido mais restrito do termo. Os tribunais são criadores de normas jurídicas gerais" (KELSEN 2005, 216) ${ }^{1}$.

Embora Kelsen equipare juiz e legislador, atribui-se ao juiz ou tribunal que produziu o precedente vinculante uma relativa "equiparação" com o legislador. Defender uma equiparação absoluta pode gerar imprecisões e até mesmo incertezas, haja vista que o precedente vinculante produzido não passou por um processo legislativo, mas é fruto de um poder delegado pela constituição e até mesmo normas infraconstitucionais, a exemplo do Código de Processo Civil.

Nesse mesmo sentido, o magistério de Juraci Mourão Lopes Filho:

Essa equiparação entre juiz e legislador não é levada em termos absolutos nem mesmo por Kelsen, porque assemelha a criação do precedente não a um processo legislativo, como seria lícito se imaginar. Indica, por outro lado, uma equiparação ao costume jurígeno, reconhecido assim pelo sistema, pois, segundo expõe, "esse tipo de criação de Direito deve ser claramente distinguido da criação de normas gerais através da prática permanente dos tribunais, i.e., através do costume" (KELSEN, 2005, P.217). (LOPES FILHO, 2017, p. 158)

Desta forma, ainda que o instituto dos precedentes vinculantes no sistema jurídico brasileiro seja uma concepção pós-positivista, é de percepção cristalina que busca sua fundamentação em termos positivistas e formalistas, ao propor que o precedente (ratio decidendi) seria uma norma geral e abstrata decorrente da decisão judicial.

Convém salientar que o poder de produzir precedentes não é atribuído ao juiz por delegação do Tribunal que integra, mas que este poder lhe é atribuído pela Constituição Federal. Conforme as observações de Lopes Filho:

\footnotetext{
${ }^{1}$ A professora Ada Pellegrini Grinover defendeu a constitucionalidade dos precedentes vinculantes no Código de Processo Civil de 2015 com arrimo nas lições de Kelsen: "E o apoio de Kelsen a respeito da função criadora do direito pelos tribunais é muito significativo: essa função, existem em todas as circunstâncias, diz ele, surge com particular evidência quando um tribunal recebe competência para produzir também normas gerais por meio de decisões com força de precedentes. Conferir a tal decisão caráter de precedente é tão só um alargamento coerente da função criadora de direito dos tribunais. Se aos tribunais é conferido o poder de criar não só normas individuais, mas também normas jurídicas gerais, estarão eles em concorrência com o órgão legislativo instituído pela Constituição, e isso significará uma descentralização da função legislativa. O que, a meu ver, é altamente positivo" ("Algumas considerações sobre a constitucionalidade do precedente vinculante previsto no Código de Processo Civil". Revista Brasileira da Advocacia. Vol. 2. Ano 1.São Paulo: RT, 2016, p. 61),
} 
Não se pode dizer, também, que um juiz tem o seu poder jurisdicional de emitir precedentes em razão de uma delegação de poder do tribunal que integra. Nem mesmo se poder dizer que a apreciação, por um tribunal local, sobre questões constitucionais se dê nos moldes de uma delegação oriunda do Supremo Tribunal federal. Para haver hierarquia, deverá haver essa série de delegações de um tribunal para o outro. Acontece que todo e qualquer magistrado, independentemente do tribunal que integra ou de seu nível na pirâmide judiciária, retira seus poderes da mesma fonte normativa: a Constituição federal. (2017, p. 159)

Em contraposição à concepção de Kelsen, tem-se o pensamento de Dworkin, para quem o Direito não pode ser concebido como um sistema fechado já que os princípios jurídicos determinam o ingresso de valores morais no Direito.

Nesse mesmo entendimento o magistério de Lopes Filho:

Dworkin constrói seu pensamento, então, entendendo que o Direito não pode ser concebido como um sistema fechado, em que o ingresso de elementos nele só seja autorizado por uma regra de reconhecimento - compreendida estritamente como um teste de pedigree -, pois os princípios jurídicos representam o ingresso de valores morais no Direito. (2017, p.163)

Conforme dito alhures, defender uma absoluta equiparação entre juiz e legislador e entre lei e precedente pode causar desconfortáveis imprecisões, haja vista que não há como se aplicar a visão do positivismo ao stare decisis. Neste mesmo entendimento:

Dessa forma, exclui-se do Direito o positivismo, porque integra Direito e moral, exigindo uma compreensão de sistematização de modo que o conteúdo de suas partes integrantes importe e interfira nas mútuas relações. Em igual medida, afasta o formalismo, porque renega o "filtro" em porta de entrada no sistema, de modo a permitir o ingresso de aspectos formais, pelo que os componentes do ordenamento jurídico não podem ser reduzidos ao que se estrutura em torno de arquétipos formais. (LOPES FILHO, 2017, p. 165)

\section{E arremata o autor, demonstrando a contraposição entre as ideias de Kelsen e Dworkin:}

A contraposição das ideias de Dworkin e Kelsen é clara, pois, como visto, este põe o precedente na condição de norma geral e abstrata obtida por meio da ampliação da norma de julgamento utilizado. Kelsen faz isso porque seu sistema jurídico é composto apenas e tão somente de normas com estrutura "Se f, então Sc". Contudo, embora se possa encontrar no precedente, ou erigir dele, uma norma nesses moldes, em razão de sua força de promulgação, não será apenas a ela que o precedente será reduzido. Há um conjunto maior de elementos que importam em sua força gravitacional variável, a qual se prefere denominar de força hermenêutica. (LOPES FILHO, 2017, p. 165)

Pelo exposto, conclui-se que apesar dos operadores do direito não terem, no Brasil, uma cultura jurídica baseada no common law, nas últimas décadas tem ocorrido uma aproximação entre os dois sistemas ${ }^{2}$. De um lado, países cuja matriz seja o direito consuetudinário têm editado leis

\footnotetext{
${ }^{2}$ A aproximação entre os dois sistemas também foi notada pela autora espanhola Leonor Moral Soriano ao prever: "No hay duda de que hoy en día las normas legislativas son cada vez más relevantes en sistemas jurídicos basados en los precedentes (los de Derecho común), mientras que, simultáneamente, en los sistemas basados en el Derecho escrito (los continentales) el uso de los precedentes judiciales es un recurso habitual en la interpretación del Derecho y la justificación de las decisiones. Esta convergencia coadyuva a la desaparición de nítidas fronteras entre ambos sistemas jurídicos. Los precedentes son de lo más elocuente al respecto: ni éstos tienen una fuerza vinculante irresistible en los
} 
com a finalidade de instituir marcos regulatórios, quando tais leis entram em vigor cessa-se a aplicação dos precedentes. De outro lado, países cuja matriz seja o civil law, como é o caso do Brasil, têm adotado a aplicação de precedentes com o fito de desafogar o Judiciário, celerizar a entrega da tutela jurisdicional e propiciar uma justiça com maior segurança jurídica, através de padronização de decisões para casos semelhantes ou repetitivos.

Noutro giro, pode-se dizer que a aproximação entre os dois sistemas jurídicos em comento, além de ser efeito do neoconstitucionalismo e pós-positivismo é, também, um dos efeitos do movimento de globalização, sendo de interesse não só do direito, mas da política de desenvolvimento da ordem econômica mundial.

Há necessidade da instituição de marcos regulatórios para temas sensíveis que envolvam interesses dos Estados, do mercado e da cidadania, ao mesmo tempo em que os Estados, o mercado e a cidadania carecem de uma jurisdição mais célere, coerente e estável, conforme preconiza o art. 926 do Código de Processo Civil pátrio. ${ }^{3}$

A maior ou menor estabilidade e confiabilidade jurídica não só do ordenamento, mas também da jurisdição, é vetor importantíssimo para aquecimento ou desaquecimento de investimentos e estreitamento ou distanciamento das relações entre os Estados contemporâneos.

\section{DEFINIÇÕES IMPORTANTES PARA SE ENTENDER O SISTEMA DOS PRECEDENTES BASEADO NO COMMON LAW}

O sistema do common Law é bastante antigo. Juristas e historiadores relatam que passou a existir há mais de mil anos, a partir do século XII, sendo reforçado no século seguinte com o advento da Magna Charta libertatum, em 1215, que se traduziu em um dos documentos jurídicos mais importantes da história. A Magna Charta Libertatum visava limitar os poderes absolutos do Rei João Sem Terra, que com suas ações se indispôs com nobres e clérigos.

Entre os atos odiosos praticados à época pelo Rei João Sem Terra destacavam-se o aumento de impostos em desfavor dos barões com fins de financiamentos bélicos e a recusa em receber representantes do clero, o que resultou em sua excomunhão da Igreja. Tais fatos, somados a muitas outras arbitrariedades, foram suficientes para que nobreza e clero se unissem para redigir uma grande carta (Magna Charta) que limitava seus poderes arbitrários. No ano seguinte ao da assinatura da Magna Charta Libertatum o rei João Sem Terra foi morto em batalha. Contudo, o documento jurídico foi muito importante para as liberdades civis e para o devido processo legal, além de servir de inspiração para movimentos constitucionalistas futuros.

Sobre o tema discorre Aline Gorga:

\footnotetext{
sistemas de Derecho común, ni son irrelevantes para los sistemas de Derecho común y de Derecho civil, determina un cambio de perspectiva en los estudios teóricos sobre el precedente: los que proceden de la cultura jurídica anglo-sajona tienden a suavizar la regla o doctrina del precedente (o stare decisis) y hablan no tanto de su fuerza (strength) cuanto de su ámbito (scope); en los sistemas de Derecho civil, por otro lado, además de los estudios en torno al valor fonticio de los precedentes, son cada vez más numerosas las obras dedicadas al análisis de su papel en la práctica judicial."( $E l$ Precedente Judicial, Madrid, Marcial Pons, 2002, p. 15/16). Essa aproximação também foi atestada pelo professor José Rogério Cruz e Tucci para quem: "Constata-se realmente que, considerado o valor, in abstrato, dos precedentes judiciais, a influência destes é deveras similar em ambos os sistemas: de fato, enquanto naqueles países que seguem o modelo da commom law, a força vinculante dos anteriores julgados tem-se tornado mais flexíveis, nos do ordenamentos codificados é incontestável a difusa e constante tendência de os juízes aterem-se aos precedentes na fundamentação da ratio decidendi." (Precedente Judicial como fonte do direito, São Paulo, Revista dos Tribunais, 2004, p. 26).

${ }^{3}$ Art. 926. Os tribunais devem uniformizar sua jurisprudência e mantê-la estável, íntegra e coerente.
} 
Apesar de estarem relacionados com a common law, a qual nasceu há mais de mil anos, "as regras e princípios regulando o uso dos precedentes e a determinação e aceitação de sua autoridade são relativamente recentes". Dessa forma pode-se dizer que apesar da fonte da common law sempre ter sido a jurisprudência, eis que é conhecida por ser um sistema extremamente pragmático, preferindo a formação do direito por meio de decisões jurisdicionais com poucos compromissos com leis em tese, a ideia de vinculação do julgado somente surgiu no século XIX, quando as decisões passaram obrigar os próprios juízes [...]. (2017, p. 126/127)

Portanto, apesar do sistema do common law ser milenar, a vinculação dos precedentes originados nos julgados oriundos deste sistema só passou a vincular juízes num passado mais recente, ou seja, a partir do século XIX.

Para se tornar um precedente (stare decisis) ${ }^{4}$ o julgado deve ser utilizado como referência para novos casos futuros que se assemelhem ao caso paradigma (leade case). ${ }^{5}$ Gifford e Salter mencionam que "dessa forma, a teoria dos precedentes se baseia no fato de que os princípios jurídicos estabelecidos nas decisões devem permanecer vigentes e aceitos como fontes primárias". (1997, p. 38)

Para se transformar em um precedente, não necessariamente há que ser a primeira decisão proferida em um determinado caso concreto. Na verdade o que transforma um julgado em precedente é a qualidade, a juridicidade substancial da decisão. Daí porque se dizer que uma decisão contém duas vertentes: uma para o caso concreto, ou seja, a parte dispositiva com força vinculante inter partes e outra que vai para além do caso julgado, trazendo todos os fundamentos hermenêuticos da decisão (ratio decidendi), podendo ser universalizável, ou seja, podendo tornarse um precedente obrigatório (stare decisis).

Conforme preleciona Marcelo Abelha:

Na decisão, no dispositivo, ele produz uma norma jurídica individual que resolve aquele caso concreto. Na fundamentação dessa decisão para aquele caso ele afirma a premissa hermenêutica para decidir, ou seja, explicita as razões de decidir, qual seja como deu-se o processo e progresso de interpretação do texto normativo para dele extrair a regra aplicável à espécie. Esta razão de decidir é uma regra abstrata universalizável, que quando fixada pelos tribunais de cúpula, responsáveis pela uniformização da interpretação do direito legislado federal e constitucional (nomofilacia) deverá ser seguido pelos órgãos jurisdicionais a ele vinculados no plano horizontal e vertical. (2016, p. 312)

Daí depreende-se que um precedente vinculante produz duas normas: uma de natureza individual e particular, destinada à solução do caso concreto, outra que vai para além do caso julgado, de natureza abstrata, universalizável, pautada na razão de decidir (ratio decidendi ou holding).

No novo sistema de precedentes vinculantes, trazido à baila pelo CPC/2015, há uma preocupação com o não engessamento do papel do juiz ou órgão jurisdicional que se vincula ao mesmo.

\footnotetext{
${ }^{4}$ Stare decisis et non quieta movere - termo completo - significa "mantenha-se a decisão e não se moleste o que foi decidido" (TUCCI, José Rogério Cruz e. Precedente Judicial como Fonte do Direito. São Paulo: Revista dos Tribunais, 2004).

${ }^{5}$ Para Fredie Didier Jr., Rafael Oliveira e Paula Braga: "Precedente é a decisão judicial tomada à luz de um caso concreto, cujo núcleo essencial pode servir como diretriz para o julgamento posterior de casos análogos". (2018, p. $513)$.
} 
Contudo, o próprio sistema de precedentes desenvolvido pelo common law apresenta soluções para não relegar o papel do juiz ou órgão jurisdicional vinculado a um plano secundário. O juiz continuará a exercer sua importante função de interpretar e aplicar o direito.

Para se aplicar o precedente vinculante o juiz ou órgão vinculado irá fazer um cotejamento entre o caso sub judice e a ratio decidendi do caso paradigmático. Logo, não é uma mera aplicação afoita e sem prévia análise das características fáticas intrínsecas que podem igualar ou mesmo diferenciar (distinguishing) um caso do outro.

Para Elpídio Donizetti:

Se não houver coincidência entre os fatos discutidos na demanda e a tese jurídica que subsidiou o precedente, ou, ainda, se houver alguma peculiaridade no caso que afaste a aplicação da ratio decidendi daquele precedente, o magistrado poderá se ater a hipótese sub judice sem se vincular ao julgamento anterior. (2015, p. 10)

Por outro lado, precedentes antes aplicáveis a determinados casos podem se tornar ultrapassados, obsoletos e não mais se adequarem à evolução dos fatos sociais.

Quando isso ocorre, dá-se o overruling, que é uma forma de superação, revogação mesmo de precedentes, que ocorre tanto no plano horizontal, quando um órgão jurisdicional revoga seu próprio precedente, quanto no plano vertical, quando um tribunal superior revoga precedente de um inferior.

No entendimento de Ataíde Junior "os requisitos básicos para a revogação de um precedente são a perda de congruência social e o surgimento de inconsistência sistêmica". (ATAIIDE JUNIOR, 2012)

A revogação de um precedente, antes em vigor, se dá por perda de eficácia para casos futuros, haja vista que tanto as relações sociais quanto o direito, não são estáticos, ou seja, o direito evolui em função das mudanças sociais. Quando um precedente se torna incoerente com o sistema não há mais como aplicá-lo a casos presentes e futuros.

\section{DEFINIÇÃO DE PRECEDENTES VINCULANTES E CLASSIFICAÇÃO DOS TIPOS DE EFICÁCIA DOS PRECEDENTES JUDICIAIS}

$\mathrm{Na}$ acepção do instituto, toda decisão judicial tem potencial de se transformar em um precedente, ${ }^{6}$ basta que seja tomada como parâmetro, ou seja, fundamento, para outra ação que se assemelhe àquela que produziu a decisão paradigma.

Nesse sentido o magistério de Medina:

É necessário, pois, realizar-se um esforço adicional, a fim de se definir o que deve conter uma decisão para ser, então, considerada um precedente. Uma decisão judicial não será, necessariamente um precedente. Tem tal natureza uma decisão que tenha potencial para servir de base para decisões judiciais de casos futuros que envolvam questões idênticas ou similares. (2016, pág. 143)

A construção de precedentes está afeta ao labor dos operadores do direito, em especial, juízes, advogados e juristas, que contribuem para a construção e reconstrução do ordenamento jurídico. Já que tanto o mundo dos fatos quanto o mundo das normas não são estáticos e evoluem, dialeticamente, conforme evoluem as relações sociais.

\footnotetext{
${ }^{6}$ Alexandre Câmara leciona que nem toda decisão judicial é precedente, somente serão precedentes aquelas que estabeleçam um fundamento determinante que será observado na formação de decisão futura.
} 
O chamado precedente (stare decisis) utilizado no modelo judicialista, é o caso já decidido, cuja decisão primeira sobre o tema (leading case) atua como fonte para o estabelecimento de diretrizes para os demais casos a serem julgados. Esse precedente, como o princípio jurídico que lhe servia de pano de fundo, haverá de ser seguido nas posteriores decisões como paradigma (ocorrendo, aqui, portanto, uma aproximação com a ideia de súmula vinculante brasileira). ${ }^{7}$

No mesmo sentido assevera Medina:

São os julgados subsequente que conferirão tal reconhecimento à decisão. Dito de outro modo, um julgado não pode se autoproclamar, substancialmente, como precedente. No caso brasileiro, a lei atribui, formalmente, a qualidade de precedente a determinadas decisões, ao exigir sua observância e sujeitar seu desrespeito a controle exercido por meio da reclamação. (2016, p. 143)

E, sobre os precedentes vinculantes, complementa Medina:

Vê-se que a força vinculante de tais decisões resulta da lei. Dá-se algo diverso no common law, como se viu. Mas no direito brasileiro, como temos insistido, não devem os Tribunais que proferirão a decisão que, a priori, é considerada vinculante (podendo ser considerada um precedente em sentido formal) contentar-se com esse reconhecimento legal. Um precedente fraco (isso é, destituído de qualidade para se transformar em um precedente em sentido substancial), ainda que tenha força vinculante formal, tenderá a não ser respeitado, justamente por não ostentar a qualidade de se fazer ser aceito pela robustez de seus fundamentos e pelo ambiente sadio em que se formou (e.g. com ampla publicação, participação de interessados, qualidade de sua fundamentação, etc). (2016, pág. 144)

Nota-se que Medina soma sua visão crítica ao que Lênio Streck denomina de "precedentes à brasileira", ${ }^{8}$ haja vista que devido à falta de uma cultura dos precedentes no judiciário brasileiro, o novo CPC impõe que determinados casos sejam previamente separados e, após serem decididos pelos tribunais, sejam transformados em precedentes. Diferentemente do direito consuetudinário norte americano, no qual o labor dos juízes produz decisões (ratio decidendi) tomadas como paradigma para casos futuros semelhantes, em razão da qualidade dos fundamentos que levaram àquela decisão (ratio decidendi) e se transformam em precedentes vinculantes (stare decisis).

\subsection{Diferença entre jurisprudência, súmula e precedente}

A esta altura faz-se necessário traçar as pertinentes características diferenciadoras entre estes três institutos jurídicos, eis que importante para melhor entendimento da proposta do novo CPC no que tange aos precedentes vinculantes.

Por jurisprudência entende-se o conjunto de decisões judiciais que têm o mesmo sentido, ou seja, que coincidem e convergem entre si. Embora a jurisprudência seja baseada em um número relativamente grande de julgados convergentes, a mesma não tem efeito vinculante e não é passível de reclamação no caso de descumprimento.

Já as súmulas são produzidas pelos tribunais, com base em seus regimentos, como forma de facilitar e tornar mais célere a ação dos juízes, assim como a jurisprudência, não goza de força vinculante, não sendo seu descumprimento passível de manejo de reclamação.

\footnotetext{
7 TAVARES, André Ramos. Nova lei da súmula vinculante: estudos e comentários à Lei 11.417 de 19.12.2006. p. 20, apud LENZA, Pedro. Direito Constitucional Esquematizado. 18 ed. São Paulo: Saraiva, 2014, p. 892.

${ }^{8}$ Lênio Streck assevera: "Em suma, é algo assim: o precedente vincula porque assim decidiu um órgão dotado de autoridade". (2016, pag. 401).
} 
Precedente, como visto alhures é todo julgado capaz de produzir uma ratio decidendi que servirá de paradigma para caso futuro que se amolde ao seu quadrante. Nos termos do art. 927 do novo CPC, os precedentes vinculam os órgãos judicantes da corte que os prolatou (vinculação horizontal) e também os órgãos judicantes hierarquicamente subordinados (vinculação vertical). precedente:

Aline Gorga presta valiosa contribuição na diferenciação entre jurisprudência, súmula e

Ocorre que, a priori, apenas o Supremo Tribunal Federal e o Superior Tribunal de Justiça formam precedentes, enquanto os Tribunais Regionais Federais e os Tribunais de Justiça dão lugar à jurisprudência. Quanto às súmulas, elas colaboram na interpretação e na aplicação do Direito, tanto das Cortes Supremas quanto das Cortes de Justiça, motivo pela qual podem emanar de ambas. (2017, pág. 135)

Uma vez apresentados os traços característicos diferenciadores dos três institutos, passa-se a classificação quanto aos tipos de eficácia dos precedentes, tomados no sentido lato, ou seja, de decisão judicial com potencial para ser um precedente vinculante, ou que apenas influencie outros julgados ou, ainda, que se limite apenas a fazer justiça entre as partes de um determinado caso concreto.

\subsection{Tipos de eficácia dos precedentes judiciais}

Da mesma forma que toda decisão judicial tem potencial para ser um precedente, pode-se afirmar que todas elas têm também uma força vinculante, o que vai variar é o grau de eficácia que cada decisão poderá produzir. Por isso a doutrina tem apresentado classificações dos tipos de eficácia dos precedentes.

A classificação da eficácia dos precedentes adotada no presente trabalho é a mesma proposta por Patrícia Perrone Campos Mello. (2008, p. 61/112).

\subsubsection{Precedente vinculante}

Também conhecido como precedente de caráter normativo, devido a sua generalidade e aplicabilidade a todos os casos semelhantes, os precedentes vinculantes, previstos no artigo 927 do CPC, devem ser de observância obrigatória por todos os órgãos do Poder Judiciário, vinculados ao órgão que produziu o precedente.

Precedentes vinculantes ${ }^{9}$ são institutos de larga utilização no sistema do common law, de matriz anglo-saxônica, países como Inglaterra e Estados Unidos têm um longo histórico na aplicação de tais precedentes, o que não ocorre no Brasil, por ser um país que adota o civil law, de matriz romano-germânica, com a aplicação do direito baseada, principalmente, em leis.

\footnotetext{
${ }^{9}$ Desde muito o professor Cândido Rangel Dinamarco já defende as decisões vinculantes: "Quando o Min. Sepúlveda Pertence, então na Presidência do Supremo Tribunal Federal, ergueu a bandeira das decisões vinculantes dos Tribunais Superiores da União não faltaram todavia vozes divergentes a sustentar a inconveniência da proposta, seja em face do princípio político da separação dos Poderes do Estado, seja do postulado da independência dos juízes ou da efetividade do contraditório. Mas a angustiosa realidade do Poder Judiciário brasileiro, sobrecarregado e moroso, exige uma solução liberta de preconceitos políticos ou jurídicos radicalizadores dessas conquistas liberais. É preciso inovar com cautela e em desapreço pelos valores residentes naqueles princípios, mas com sabedoria e coragem suficientes para saber em que medida hão de prevalecer e como precisam ser harmonizados certos valores eventualmente conflitantes." (Fundamentos do processo civil moderno; efeito vinculante das decisões judiciárias. $3^{\mathrm{a}}$ ed., vol 2, São Paulo: Malheiros, 2.000, p. 1.123).
} 
A possibilidade de reclamação à Corte que deu origem ao precedente, no caso de desrespeito ao mesmo, é uma das principais ferramentas à disposição das partes e do Ministério Público, para construção de uma cultura dos precedentes no direito pátrio. O instituto da representação também divide opiniões, quanto à sua constitucionalidade, gerando ainda mais polêmica quando o tema é precedente vinculante e reclamação contra seu descumprimento.

A respeito do instituto da reclamação contra descumprimento de precedentes vinculantes destaca-se o $\S 3^{\circ}$ do art. 103-A da $\mathrm{CF} / 88$, reclamação contra desrespeito a súmulas vinculantes do STF e o art. 988 do CPC que prevê o manejo da reclamação para: I - preservar a competência do tribunal; II - garantir a autoridade das decisões do tribunal; III - garantir a observância de enunciado de súmula vinculante e de decisão do Supremo Tribunal Federal em controle concentrado de constitucionalidade; IV - garantir a observância de acórdão proferido em julgamento de incidente de resolução de demandas repetitivas ou de incidente de assunção de competência.

Nos moldes dos $\S \S 1^{\circ}$ e $2^{\circ}$ do art. 988 do CPC a reclamação pode ser proposta perante qualquer tribunal, e seu julgamento compete ao órgão jurisdicional cuja competência se busca preservar ou cuja autoridade se pretenda garantir. A reclamação deverá ser instruída com prova documental e dirigida ao presidente do tribunal.

No magistério de Marinoni, Arenhart e Mitidiero: "Até que as Cortes Supremas, as Cortes de Justiça e os juízes de primeiro grau assimilem uma efetiva cultura do precedente judicial, é imprescindível que se admita a reclamação com função de outorga de eficácia de precedente." (2015. p. 920).

No Direito Brasileiro podem ser citados como exemplos de precedentes vinculantes as seguintes decisões: as súmulas vinculantes, previstas no art. 103-A da Constituição Federal; as decisões proferidas em sede de controle concentrado de constitucionalidade, que devem ser observadas por todos os demais órgãos do Poder Judiciário; acórdão proferido em julgamento de incidente de resolução de demandas repetitivas ou de incidente de assunção de competência. Todas podendo ser objeto de reclamação no caso de não aplicação do efeito vinculante, nos moldes do art. 988 do CPC.

\subsubsection{Precedentes de eficácia intermediária}

Os precedentes de eficácia intermediária possuem eficácia que vai para além do caso concreto gerador da decisão. Devem ser observados pelos demais órgãos do Judiciário, contudo, em caso de não observância, não ensejam a propositura de reclamação perante o órgão prolator da decisão.

Tais precedentes são classificados como de eficácia intermediária por seu efeito (força) vinculante estar situada entre os precedentes vinculantes e os precedentes de eficácia persuasiva.

Como exemplo de precedentes de eficácia intermediária temos os julgados proferidos pelo Supremo em casos de repercussão geral, bem como a jurisprudência dominante dos tribunais superiores, das quais o descumprimento pelos demais órgãos judiciais não ensejam a propositura de reclamação.

\subsubsection{Precedentes de eficácia persuasiva}

São aqueles que têm eficácia inter partes, ou seja, se aplicando apenas ao caso sub judice. Não obstante, não se pode olvidar que todo julgado tem potencial para ser um precedente, embora não tenha eficácia para além do caso julgado, pode ser utilizado pelos operadores do direito como paradigma em outra ação semelhante. 
Por terem eficácia apenas no caso concreto, não vinculam os demais órgãos do Judiciário e, portanto, não são passíveis de reclamação.

Mesmo sendo o precedente de menor eficácia vinculativa não há como negar sua importância, já que pode ser suscitado como base de fundamentação em ações semelhantes, demonstrando que a pretensão já foi acolhida por outro órgão julgador. Caso o julgado seja utilizado reiteradas vezes pode integrar entendimento jurisprudencial, contribuindo para a redução de decisões contraditórias e para conferir ao direito unidade, conformidade, estabilidade e coerência.

\section{DA (IN)CONSTITUCIONALIDADE DOS PRECEDENTES VINCULANTES PREVISTOS NO ART. 927, III, IV e V do CPC}

O cerne da presente pesquisa é a questão da constitucionalidade ou inconstitucionalidade dos precedentes normativos, em especial quanto aos incisos III, IV e V do art. 927 do CPC/2015, já que as súmulas vinculantes e controle concentrado de constitucionalidade a cargo do STF têm autorização constitucional.

No que tange a esta questão processualistas e constitucionalistas vêm apresentando posições divergentes.

\subsection{Juristas que defendem a inconstitucionalidade dos precedentes vinculantes}

Aqueles que defendem a inconstitucionalidade, especialmente dos incisos III, IV e V do art. 927 do CPC, alegam que ao instituir precedentes vinculantes no sistema jurídico brasileiro, que se baseia na civil law e na tripartição e independência dos poderes, o Poder Judiciário estaria a invadir esfera de competência do Poder Legislativo, pois eis que os precedentes vinculantes, por terem caráter geral, com aplicação erga omnes, estariam a configurar verdadeiros diplomas legais. Editar leis no Brasil é competência precípua do Poder Legislativo e, excepcionalmente, com supedâneo em autorização constitucional, poderia o Poder Judiciário expedir tais precedentes com caráter normativo.

Os juristas que pugnam pela inconstitucionalidade dos precedentes vinculantes entendem que deveria se proceder com as mesmas formalidades utilizadas ao se tratar das súmulas vinculantes, que teve longa etapa de estudos e debates e culminou com previsão constitucional autorizativa de edição das mesmas pelo STF.

Conforme o entendimento de Nelson Nery Junior:

STF e STJ, segundo a CF 102 e 105, são tribunais que decidem casos concretos, que resolvem lides objetivas (e.g. ADIn) e subjetivas (e.g. RE e REsp). Não legislam para todos, com elaboração de preceitos abstratos: salvo quanto à súmula vinculante (STF, CF 103-A). Não são tribunais de teses. (2016, pág. 1963).

O processualista Nelson Nery Junior afirma que atribuir tal poder ao Judiciário através de lei ordinária (CPC) estaria a hipertrofiar o Poder Judiciário, propiciando que o mesmo diga o direito através de tais precedentes em detrimento do ordenamento jurídico pátrio, em especial a Constituição Federal.

Nelson Nery Junior, em entrevista ao Jornal Jota.com, menciona que ao instituir os precedentes normativos por norma infraconstitucional seria o mesmo que o Judiciário dizer: "esqueçam a lei, a Constituição e a doutrina, porque o que vale agora é o que eu, Tribunal, disser". 
E continua, ainda, o advogado, professor e doutor em Direito Processual Civil: "Baixar um texto normativo vinculativo com eficácia geral e abstrata - isso é lei. Para o Judiciário legislar, desculpe, precisa de autorização da Constituição". ${ }^{10}$

Para Nelson Nery Junior, por não haver previsão de precedentes vinculantes na Constituição Federal, o Poder Judiciário se apoderou de um poder que não tem. Respondendo pergunta sobre a possibilidade de uma tese de inconstitucionalidade da vinculação das decisões judiciais evoluir, o jurista vaticina: "Nenhuma chance. Foram os ministros do Supremo e do STJ que criaram o núcleo duro do CPC, o direito jurisprudencial. Como o Supremo vai dizer que fez algo inconstitucional? Vão dar uma pedalada jurídica para dizer que é constitucional."11

Para o advogado e professor Georges Abboud, " a instituição do sistema de decisões vinculativas dentro desse cenário levará o Judiciário a concentrar a criação e aplicação da norma, rachando a tripartição dos poderes e o regime democrático". ${ }^{12}$

No mesmo sentido, José Maria Tesheiner ${ }^{13}$ também alega a inconstitucionalidade dos precedentes vinculantes previstos no novo $\mathrm{CPC}$ :

O mesmo artigo 927 atribui poder normativo às súmulas do Supremo Tribunal Federal em matéria constitucional e às do Superior Tribunal Federal em matéria infraconstitucional (inciso IV). Trata-se, também aí, de indevida atribuição legislativa aos tribunais, por simples lei ordinária. O Código de Processo Civil atreve-se, assim, a inovar sobre as próprias fontes do Direito. $(2015)^{14}$

Outros juristas pugnam pela inconstitucionalidade do instituto, repetindo teses aqui já expostas, portanto, devido ao apertado da análise, o presente trabalho limitar-se-á aos juristas supramencionados.

\subsection{Juristas que defendem a constitucionalidade dos precedentes vinculantes}

Dentre os juristas que defendem a constitucionalidade do art. 927 do CPC em sua íntegra podemos destacar os seguintes: Luiz Guilherme Marinoni, Humberto Theodoro Junior, Elpídio Donizetti, Thiago Fillipo, Patrícia Perrone Campos Mello e Luis Roberto Barroso, dentre outros. Para estes os precedentes vinculantes são importantes para a efetivação tanto do art. $5^{\circ}$, LXXVIII, da Constituição Federal, ou seja, a razoável duração do processo, quanto para a uniformização da jurisprudência e manutenção da estabilidade, integridade e coerência da mesma, nos moldes do art. 926 do CPC/2015.

Perrone e Barroso afirmam que:

Três valores principais justificam a adoção de um sistema de precedentes normativos ou vinculantes: a segurança jurídica, a isonomia e a eficiência. A obrigatoriedade de observar

\footnotetext{
${ }^{10}$ Acessível em: https://jota.info/justica/nucleo-duro-novo-cpc-e-inconstitucional-diz-jurista-21122016.

${ }^{11}$ Idem. Em seu Código de processo Civil Comentado Nelson Nery Júnior Previu expressamente que "esses preceitos vinculam juízes e tribunais, vinculação essa de inconstitucionalidade flagrante. O objetivo almejado pelo CPC927 necessita ser autorizado pela CF. Como não houve modificação na CF para propiciar ao Judiciário legislar, como não se obedeceu ao devido processo, não se pode afirmar a legitimidade desse instituto previsto no texto comentado." (Código de Processo Civil comentado, 16 ed., São Paulo: RT, 2016, p. 1963).

12 Ibidem.

${ }^{13}$ Professor de Processo Civil na Pontifícia Universidade Católica do Rio Grande do Sul; Desembargador aposentado do Tribunal de Justiça do mesmo Estado.

14 Disponível em: https://www.paginasdedireito.com.br/index.php/artigos/317-artigos-set-2015/7376inconstitucionalidades-gritantes-no-artigo-927-do-novo-cpc
} 
as orientações já firmadas pelas cortes aumenta a previsibilidade do direito, torna mais determinadas as normas jurídicas e antecipa a solução que os tribunais darão a determinados conflitos. O respeito aos precedentes constitui um critério objetivo e prédeterminado de decisão que incrementa a segurança jurídica. A aplicação das mesmas soluções a casos idênticos reduz a produção de decisões conflitantes pelo Judiciário e assegura àqueles que se encontram em situação semelhante o mesmo tratamento, promovendo a isonomia. ${ }^{15}$

Também defendendo que a adoção de precedentes obrigatórios não fere a repartição de poderes temos as palavras de Thiago Fillipo, que defende:

[...] respeitadas as posições contrárias, temos que a edição de precedentes obrigatórios tal como proposto pelo novo Código de Processo Civil, independentemente da roupagem que assumam, não implica qualquer lesão ao princípio da separação de poderes porque, malgrado a sua força vinculante, eles não possuem o condão de substituir a função das leis. $(2015$, p. $441 / 442)$

No mesmo sentido é o entendimento da professora Teresa Arruda Alvim, que é uma das Autoras que mais se dedica ao estudo dos precedentes em nosso país:

A nós, nos parece absolutamente clara a inexistência de inconstitucionalidades nestes dispositivos e em tantos outros do Código em que se reconhece a função normativa da jurisprudência, ou, melhor ainda, de parâmetros oriundos do Judiciário (já que súmulas não são jurisprudência). Afinal, decisões são baseadas em textos de lei, textos devem ser COMPREENDIDOS, INTERPRETADOS. Nada mais natural do que se adotar interpretação que prevaleceu em súmula (vinculante ou não) ou em repetitivo (ainda que não houvesse a perspectiva de esse "desvio" ser corrigido pela reclamação (art. 988, § 5', II).( 2018, p. 769)

Com base nas citações supra, percebe-se que da mesma forma que existe expressiva corrente que brada pela inconstitucionalidade dos precedentes obrigatórios, existe também uma expressiva corrente que defende a constitucionalidade dos mesmos.

Fato é que os milhões de processos que abarrotam os órgãos do Judiciário bradam ainda mais alto que qualquer tese contrária ou a favor dos precedentes vinculantes. ${ }^{16} \mathrm{~A}$ justiça brasileira precisa encontrar um caminho para desafogar os tribunais e prestar a tão almejada tutela jurisdicional aos cidadãos ${ }^{17}$, sem olvidar que nos dizeres de Rui Barbosa: "justiça atrasada não é

\footnotetext{
15 〈https://www.conjur.com.br/dl/artigo-trabalhando-logica-ascensao.pdf >

${ }^{16}$ Flávio Luiz Yarshell examina alguns obstáculos que impedem que a jurisprudência seja uniforme, estável, íntegra e coerente, com destaque para resistência oposta às decisões uniformizadoras que podem advir das partes ou mesmo de quem julga. Para o Autor: "Se e enquanto tais obstáculos não puderem ser superados, será difícil obter segurança, previsibilidade e isonomia. E se tais objetivos não puderem ser atingidos, talvez esse indesejável estado de coisas contribua, ainda que de forma oblíqua, para a constatação de que todos precisamos cada vez mais nos voltar também para os mecanismos não apenas de soluções não adjudicadas de conflitos, mas que sejam aptos a preveni-los, de sorte a atuar de forma profilática. Para usar uma imagem, se não houver doentes, não haverá mais a preocupação de tratalos de maneira uniforme. Pensemos nisso." ("Jurisprudência uniforme, estável, integra e coerente: Obstáculos Superáveis?" in Estudos de Direito Processual Civil em homenagem ao Professor José Rogério Cruz e Tucci, Salvador: JusPodivm, 2018, p. 307).

${ }^{17}$ Segundo Ronaldo Cramer: "Quando o Judiciário não respeita seus precedentes, a sociedade, mesmo nas causas repetitivas, vale-se da ação judicial como aposta para buscar a solução judicial mais conveniente. De fato, quando os precedentes não têm força ou têm força fraca, vale a pena litigar em juízo, já que a ação judicial pode entregar qualquer resposta, inclusive contrária a posicionamento já tomado pelo próprio Judiciário. Entretanto, num sistema em que os precedentes são observados, o contrário ocorre. Há um desestímulo à litigância, uma vez que, se o Judiciário já fixou
} 
justiça, senão injustiça manifesta e qualificada". Por outro lado, fazendo o trocadilho com o pensamento do saudoso jurista, justiça afobada e mal fundamentada também não é justiça, senão injustiça manifesta e qualificada.

Portanto, fazendo remissão à balança como um dos símbolos do direito e da justiça, o Judiciário brasileiro há que encontrar o equilíbrio necessário na aplicação de precedentes obrigatórios, em seu mister de construção e reconstrução do direito, juntamente com demais operadores do direito e a participação popular. Afinal, todo poder emana do povo!

\section{CONCLUSÃO}

Quanto a eventuais inconstitucionalidades no instituto dos precedentes vinculantes, nos moldes do art. 927 do CPC/2015, processualistas e constitucionalistas dividem-se em suas opiniões e a polêmica não parece nem perto de ser solucionada, mesmo porque o Poder Judiciário, ao qual os juristas atribuem a idealização do art. 927 do CPC, que versa sobre os precedentes vinculantes é o mesmo que, através da Suprema Corte, analisará eventuais ações de inconstitucionalidade do artigo sob comento.

Alguns juristas anunciam a inconstitucionalidade dos precedentes vinculantes motivada por previsão apenas infraconstitucional, dentre eles destacam-se Nelson Nery Junior, Georges Abboud, Pedro Lenza e José Maria Tesheiner. Os que alegam a inconstitucionalidade sustentam que, por terem caráter vinculante, portanto com carga normativa, são consideradas verdadeiras normas de caráter geral, desta forma estariam afetas ao poder de legislar que não é atividade precípua do Judiciário, cuja atividade constitucional é prestar a tutela jurisdicional.

Pedro Lenza menciona: "Em nosso entender, essas regras de vinculação não poderiam ter sido introduzidas por legislação infraconstitucional, mas, necessariamente, por emenda constitucional a prever outras hipóteses de decisões com efeito vinculante, além daquelas já previstas na Constituição."18

E acrescentam, os defensores da inconstitucionalidade, que ao adotar os precedentes vinculantes o Brasil está a importar instituto do sistema do common law, baseado na primazia da decisão judicial (judge made Law), modelo incompatível com nosso sistema de matriz baseada no civil Law, que tem primazia na lei criada pela vontade popular, vontade esta representada pelo Poder Legislativo ou mesmo por iniciativa popular nos termos da Constituição. Estaria, assim, a ofender a separação e independência dos poderes da república.

Aqueles que advogam a constitucionalidade dos precedentes vinculantes, tais como Luiz Guilherme Marinoni, Teresa Arruda Alvim, Humberto Theodoro Junior, Luis Roberto Barroso, dentre outros, entendem que tais precedentes seriam importantes para atendimento do previsto no art. $5^{\circ}$, LXXVIII, da Constituição Federal, ${ }^{19}$ bem como para cumprimento no disposto no art. 926 do CPC, ${ }^{20}$ por contribuírem com a redução do grande número de processos tramitando por longos anos nos juízos e tribunais e, com isso, atender à razoável duração do processo, padronização de

\footnotetext{
seu entendimento sobre a questão, as chances de uma ação obter resultado diferente são pequenas." (Precedentes Judiciais Teoria e Dinâmica, Rio de Janeiro: Forense, 2016, p. 62/63).

${ }^{18}$ LENZA, Pedro. Reclamação constitucional: inconstitucionalidades no Novo CPC/2015. Disponível em: <https://www.conjur.com.br/2015-mar-13/pedro-lenza-inconstitucionalidades-reclamacao-cpc>. Acesso em: 15 nov2017.

${ }^{19}$ LXXVIII a todos, no âmbito judicial e administrativo, são assegurados a razoável duração do processo e os meios que garantam a celeridade de sua tramitação.

${ }^{20}$ Art. 926. Os tribunais devem uniformizar sua jurisprudência e mantê-la estável, íntegra e coerente.
} 
decisões judiciais em processos semelhantes baseados em causas repetitivas, o que daria ensejo a uma maior segurança jurídica. ${ }^{21}$

Em apertada síntese, são estes os argumentos que sustentam as duas correntes opositoras: os que pugnam pela inconstitucionalidade e aqueles que defendem a constitucionalidade.

O principal objetivo do presente trabalho é fazer uma analogia entre as duas correntes, através de revisão bibliográfica, trazendo à baila o pensamento da mais renomada doutrina a respeito da ampliação de precedentes vinculantes, outrora representados apenas pelas súmulas vinculantes e pelos julgados no controle concentrado de constitucionalidade, à cargo da Suprema Corte.

Desenvolveu-se, ainda, a conceituação, classificação e fez-se um breve comparativo entre o instituto nos sistemas do common law e civil law, além de trazer à baila críticas, elogios e anseios a respeito do instituto.

No sentido de se criar uma cultura dos precedentes, importante mencionar entendimento esposado por Rogerio Mollica, em sua tese de doutoramento pela USP, ${ }^{22}$ defendida antes mesmo da publicação do novo CPC, mas que também já previa, com base em estudos do art. 285-A do CPC/1973:

É de suma importância dar maior valor aos precedentes judiciais e que eles sejam respeitados pelo próprio tribunal que os prolatou e pelos juízes vinculados a esse tribunal. Somente com a previsibilidade de julgamentos uniformes e que respeitem a segurança jurídica é que poderemos racionalizar o trabalho do judiciário e dar vazão aos milhões de processos que atolam as nossas Cortes. Não cabe mais indagar que o juiz tem o seu livre convencimento abalado, no caso de dever decidir de acordo com os precedentes dos Tribunais Superiores. Não faz sentido o juiz decidir de forma completamente contrária aos julgados dos Tribunais Superiores e obrigar a parte a despender tempo e dinheiro para alcançar essas Cortes para, só então, ter reconhecido o seu direito, que já deveria ter sido assegurado pelo juiz de primeiro grau. (2010, p. 229)

Este é o panorama que se descortina com o advento do novo $\mathrm{CPC}$, em especial no que tange às divergências provocadas pela ampliação dos precedentes vinculantes, nos incisos III a V do art. 927, com uma corrente que defende a constitucionalidade e outra que brada pela inconstitucionalidade.

O Poder Legislativo aprovou o CPC/2015 nos moldes em que se encontra atualmente, logo, somente lei posterior ou decisão em ação que argua a inconstitucionalidade serão capazes de mudar o status quo vigente.

Enquanto isso, que o Poder Judiciário brasileiro trilhe o melhor caminho possível, no intuito de construir bons precedentes obrigatórios e, também, aprimorar uma cultura dos precedentes, que venha a atender os reclames do art. 926 do CPC e, principalmente, o clamor dos jurisdicionados.

Os autores do presente trabalho se filiam à corrente que manifesta pela constitucionalidade dos precedentes vinculantes, por entenderem que o instituto está amparado por direitos humanos fundamentais e princípios constitucionais que os regem e norteiam, a saber: devido e justo processo legal, duração razoável do processo e segurança jurídica.

\footnotetext{
${ }^{21}$ Com respeito ao artigo 926 do CPC Medina menciona: “O código de Processo Civil de 2015 manifesta preocupação contundente com a ideia de integridade da jurisprudência. Esta, além de íntegra, deve ser estável e coerente. (cf. art. 926)" (2016, p. 130)

${ }^{22}$ MOLLICA, Rogerio. Os processos repetitivos e a celeridade processual. Tese de doutorado apresentada na Faculdade de Direito da Universidade de São Paulo, 2010, inédita.
} 
Ademais o inevitável processo de globalização, que influencia e advoga interesses voltados para direitos humanos universais e, inegavelmente, interesses do mercado mundial, propicia uma aproximação entre os sistemas do common law e civil law, na busca de uma maior segurança jurídica nas decisões proferidas pelas cortes. Portanto, uma maior homogeneização nas decisões judiciais de demandas repetitivas é capaz de contribuir para o aumento da credibilidade e confiança no Judiciário brasileiro.

\section{REFERÊNCIAS}

ALVIM. Teresa Arruda. "Jurisprudência Brasileira - Precedentes Estrangeiros; Uma combinação Possível?" in Estudos de Direito Processual Civil em homenagem ao Professor José Rogério Cruz e Tucci, Salvador: JusPodivm, 2018.

ATAÍDE JÚNIOR, Jaldemiro Rodrigues de. Precedentes vinculantes e irretroatividade do direito no sistema processual brasileiro: os precedentes dos tribunais superiores e sua eficácia temporal. Curitiba: Juruá, 2012.

BRASIL. Constituição da República Federativa do Brasil de 1988.

Brasil. Lei 13.105 de 16 de março de 2015. Código de Processo Civil Brasileiro.

COSTA NETO, José Wellington Bezerra da. Vinculação a precedentes e livre convencimento judicial. Revista de Processo - RePro 266, 2017, p. 447/480.

CRAMER, Ronaldo. Precedentes Judiciais Teoria e Dinâmica, Rio de Janeiro: Forense, 2016.

DIDIER JR, Fredie; OLIVEIRA, Rafael Alexandria de; BRAGA, Paula Sarno. Curso de Direito Processual Civil, 13 ed, Salvador: Juspodium, 2018.

DINAMARCO, Cândido Rangel. Fundamentos do processo civil moderno; efeito vinculante das decisões judiciárias. $3^{\mathrm{a}}$ ed., vol 2, São Paulo: Malheiros, 2.000.

DONIZETTI, Elpídio. A força dos precedentes no Código de Processo Civil. http://www.revistas.unifacs.br/index.php/redu/article/viewFile/3446/2472\%20Acesso\%20em\%20 05.09.2015. Acesso em 15 de novembro de 2017.

DWORKIN, Ronald. Levando os direitos a sério. Traduzido por Nelson Boeira. São Paulo: Martins Fontes, 2002.

FILLIPO, Thiago Baldani Gomes de. Precedentes judiciais e separação de poderes. Revista de Processo - RePro 247, 2016, p. 423/448.

GORGA, Aline Medeiros. O uso dos precedentes vinculantes no ordenamento brasileiro e sua relação com o direito comparado. Revista de Direito Constitucional e Internacional - RDCI $n^{\circ}$ 112,2017 , p. 125/146. 
GRINOVER, Ada Pellegrini. “Algumas considerações sobre a constitucionalidade do precedente vinculante previsto no Código de Processo Civil”. Revista Brasileira da Advocacia. Vol. 2. Ano 1. São Paulo: RT, 2016.

KELSEN, Hans. Teoria pura do direito. Tradução de João Baptista Machado. São Paulo: Martins Fontes, 1999.

LENZA, Pedro. Reclamação constitucional: inconstitucionalidades no Novo CPC/2015. Disponível em: https://www.conjur.com.br/2015-mar-13/pedro-lenza-inconstitucionalidadesreclamacao-cpc. Acesso em 15 de novembro de 2017.

LOPES FILHO, Juraci Mourão. Sistematização de precedentes e ordenamento jurídico: proposta de um paradigma teórico. In Revista de Direito Brasileira. São Paulo-SP, v. 18, n. 7, p.149-172, Set./Dez. 2017.

MARINONI. Luiz Guilherme. ARENHART, Sérgio Cruz. MITIDIERO Daniel. Novo código de processo civil comentado. - São Paulo: Editora Revista dos Tribunais, 2015.

MEDINA, José Miguel Garcia. Integridade, estabilidade e coerência da jurisprudência no Estado Constitucional e Democrático de Direito: o papel do precedente, da jurisprudência e da súmula, à luz do CPC/2015. Revista dos Tribunais - RT 974, 2016, p. 129/154.

MELLO, Patrícia Perrone Campos; BARROSO, Luis Roberto. Trabalhando com uma nova lógica: a ascensão dos precedentes no direito brasileiro. Disponível em:

https://www.conjur.com.br/dl/artigo-trabalhando-logica-ascensao.pdf. Acesso em 15 de novembro de 2017.

MELLO, Patrícia Perrone Campos. Precedentes: o desenvolvimento judicial do direito no constitucionalismo contemporâneo. Rio de Janeiro: Renovar, 2008.

MELLO, Patrícia Perrone Campos. O Supremo e os precedentes constitucionais: como fica a sua eficácia após o Novo Código de Processo Civil. Universitas Jus, Brasília, v. 26, n. 2, jul./dez. 2015, p. 41-54;

MOLLICA, Rogerio. Os processos repetitivos e a celeridade processual. Tese de doutorado apresentada na Faculdade de Direito da Universidade de São Paulo, 2010, inédita.

NERY JUNIOR, Nelson; NERY, Rosa Maria de Andrade. Código de Processo Civil Comentado. $16^{\mathrm{a}}$ ed. rev. atual. ampl. São Paulo: Editora Revista dos Tribunais, 2016.

RAMOS, Carlos Henrique; MOUSINHO, Isabel Ribeiro. O novo Código de Processo Civil e o sistema de precedentes vinculantes. Revista Brasileira de Direito Processual, Belo Horizonte, ano 25, no 98, p. 57/94, 2017.

RODRIGUES, Marcelo Abelha. Sistema de precedentes ou meros filtros redutores de demandas repetitivas? Angústias e desconfianças. Revista de Processo - RePro 259, 2016, p. 307/329.

SORIANO, Leonor Moral. El Precedente Judicial, Madrid, Marcial Pons, 2002. 
STRECK, Lenio Luiz; RAATZ, Igor. A teoria dos precedentes à brasileira, entre o solipsismo judicial e o positivismo jurisprudencialista ou "de como o mundo (não) é um brechó". Revista de Processo - RePro 262, p. 379/ 411.

TESHEINER, José Maria. Inconstitucionalidades gritantes no artigo 927 do novo CPC. Disponível em: http://www.tex.pro.br/index.php/artigos/317-artigos-set-2015/7376inconstitucionalidades-gritantes-no-artigo-927-do-novo-cpc. Acesso em 15 de novembro de 2017.

THEODORO JUNIOR, Humberto. Jurisprudência e precedentes vinculantes no novo Código de Processo Civil - demandas repetitivas. Revista de Processo - RePro 255, 2016, p. 259/372.

TUCCI, José Rogério Cruz e. Precedente Judicial como Fonte do Direito. São Paulo: Revista dos Tribunais, 2004.

YARSHELL, Flávio Luiz. "Jurisprudência uniforme, estável, integra e coerente: Obstáculos Superáveis?" in Estudos de Direito Processual Civil em homenagem ao Professor José Rogério Cruz e Tucci, Salvador: JusPodivm, 2018. 